\title{
Variation in Boron Availability Alters Root Architecture Attributes at the Onset of Storage Root Formation in Three Sweetpotato Cultivars
}

\author{
Arthur Villordon and Jeffrey C. Gregorie \\ LSU AgCenter Sweet Potato Research Station, 130 Sweet Potato Road, \\ Chase, LA 71324
}

Additional index words. anomalous cambium, boron, Ipomoea batatas, lateral roots, root system architecture

\begin{abstract}
The primary objective of this work was to generate species-specific information about root architectural adaptation to variation in boron (B) availability at the onset of storage root formation among three sweetpotato [Ipomoea batatas (L.) Lam] cultivars (Beauregard $=$ BX; Murasaki $=$ MU; Okinawa $=$ OK). Three B levels were used: 0B $(B$ was omitted in the nutrient solution, substrate $B=0.1 \mathrm{mg} \cdot \mathrm{kg}^{-1}$ ), $1 \mathrm{XB}$ (sufficient $B ; 0.5$ $\mathrm{mg} \cdot \mathrm{kg}^{-1}$ ), and 2 XB (high $B ; 1 \mathrm{mg} \cdot \mathrm{kg}^{-1}$ ). The check cultivar BX showed evidence of storage root formation at 15 days in $\mathrm{OB}$ and $1 \mathrm{XB}$, whereas cultivars $\mathrm{MU}$ and $\mathrm{OK}$ failed to show evidence of root swelling. The $1 \mathrm{XB}$ and $2 \mathrm{XB}$ levels were associated with $736 \%$ and $2269 \%$ increase in leaf tissue $B$ in BX, respectively, relative to plants grown in 0B. Similar magnitudes of increase were observed in MU and OK cultivars. There were no differences in adventitious root (AR) count within cultivars but $O K$ showed $25 \%$ fewer AR numbers relative to $B X$ across all $B$ levels. $O B$ was associated with $20 \%$ and $48 \%$ reduction in main root length in $B X$ and $\mathrm{OK}$, respectively, relative to plants grown in $1 \mathrm{XB}$ and $2 \mathrm{XB}$. 2XB was associated with a $10 \%$ increase in main root length in $\mathrm{MU}$ relative to plants grown in $0 \mathrm{~B}$ and $1 \mathrm{XB}$. $0 \mathrm{~B}$ was associated with reduced lateral root length in all cultivars but the magnitude of responses varied with cultivars. These data corroborate findings in model systems and well-studied crop species that $B$ deficiency is associated with reduced root growth. These data can be used to further understand the role of cultivar-specific responses to variation in $B$ availability in sweetpotato.
\end{abstract}

The $\mathrm{B}$ requirement of plants is speciesdependent, yet the range between $\mathrm{B}$ deficiency and toxicity in plants is narrow (Goldberg, 1997). Globally, B micronutrient

Received for publication 13 July 2021. Accepted for publication 1 Sept. 2021.

Published online 18 October 2021.

Approved for publication by the Director of the Louisiana Agricultural Experiment Station as manuscript number 2021-260-36565. Mention of trademark, proprietary product or method, and vendor does not imply endorsement by the Louisiana State University Agricultural Center or its approval to the exclusion of other suitable products or vendors. Portions of this research were supported by Hort Innovation (Australia) and the Louisiana Sweetpotato Advertising and Development Fund. This material is based on work that is supported by the National Institute of Food and Agriculture, U.S. Department of Agriculture, Hatch projects.

We would like to acknowledge our colleagues from Queensland DAF (Australia), in particular Sandra Dennien, Rachael Langenbaker, Emma Crust, and Michael Hughes for securing funding from Hort Innovation (Australia) and for the initial experimental studies at Bundaberg Research Facility (DAF Queensland) that led to this follow-up work. We acknowledge the assistance of Zy Climaco and Presley Williams in the conduct of this work.

A.V. is the corresponding author. E-mail: avillordon@agcenter.lsu.edu.

This is an open access article distributed under the CC BY-NC-ND license (https://creativecommons. org/licenses/by-nc-nd/4.0/). deficiency is considered widespread (Shorrocks, 1997; Tariq and Mott, 2007). Investigations of B deficiency in plants show that $\mathrm{B}$ is necessary for proper plant development, as it leads to root, leaf, flower, and meristem defects (reviewed in Matthes et al., 2020). Cumulative evidence appears to support the hypothesis that root growth is more sensitive to B deficiency than shoot growth (reviewed in Brdar-Jokanović, 2020). Soil B deficiency is typically found in humid regions with well-drained soils (Tanaka and Fujiwara, 2008). In contrast, under low rainfall conditions, B cannot be sufficiently leached and may accumulate to levels that may become toxic to plant growth (Reid, 2007). A primary phenotypic effect of B toxicity in plants is root growth inhibition (reviewed in Princi et al., 2016). Evidence also exists that supports the hypothesis that $\mathrm{B}$ interacts with the uptake of other mineral nutrients (reviewed in Bariya et al., 2014; Fageria, 2001). In sweetpotato (Ipomoea batatas), B has been associated with storage root disorders such as splitting (Byju et al., 2007) and blister (Miller and Nielsen, 1970). There are published leaf sufficiency ranges (Mills and Jones, 1996), but very little information is available about newer cultivars. Despite the documented role of B in sweetpotato storage root quality, considerable knowledge gaps still exist in terms of understanding how the sweetpotato adapts to B deficiency and toxicity, especially during the critical stages of plant establishment, initial root growth, and storage root formation. Thus, expanding knowledge about B deficiency and toxicity in sweetpotato is of fundamental and practical importance in this globally important crop.

One of the means that plants adapt to variation in soil nutrient availability is by altering root system architecture (RSA) (reviewed in Giehl et al., 2014). In sweetpotato, the successful emergence and development of lateral roots, the main determinant of RSA, determines the competency of ARs to undergo storage root formation (Villordon et al., 2012). Hence, knowledge about intrinsic and environmental variables that control RSA development contribute to the understanding of storage root formation and productivity. The primary objective of this work was to generate species-dependent information about root architectural responses to variation in B availability at the onset of storage root formation in three sweetpotato commercial cultivars with contrasting storage root characteristics and storage root yield potential. A secondary objective was to generate preliminary information on the possible interaction of $B$ with the uptake of other mineral nutrients.

\section{Materials and Methods}

Plant materials and experimental conditions. The greenhouse experiments were carried out from 24 Nov. to 8 Dec. and 15 to 30 Dec. 2020 in Chase, LA (lat. $32^{\circ} 6^{\prime} \mathrm{N}$, long. $\left.91^{\circ} 42^{\prime} \mathrm{W}\right)$. Supplementary plantings were conducted on 29 Mar. and 13 Apr. 2021. These supplementary plantings were harvested at 50 $\mathrm{d}$ to confirm the presence of storage roots in experimental treatments that showed delayed storage root formation (appearance of anomalous cambium) at $15 \mathrm{~d}$ after planting and to monitor the progression of deficiency and toxic symptoms in leaves (Supplemental Figs. 1A, 2B and C). In addition, supplemental 5day plantings of cuttings grown in liquid medium (Supplemental Fig. 1B) were conducted to verify that $\mathrm{B}$ was not an absolute requirement of $\mathrm{AR}$ emergence from cuttings as documented in other species (Jarvis et al., 1983; Josten and Kutschera, 1999). The following cultivars were used: Beauregard (BX), Murasaki (MU), and Okinawa (OK). Cultivar descriptions and other pertinent information are presented in Table 1. The cultivar BX was considered as a "check" or "control" cultivar for storage root formation, defined as the appearance of anomalous cambium (Togari, 1950) at $15 \mathrm{~d}$ in the growing conditions used for the current study as well as prior work (Villordon et al., 2020). BX is a copper-skinned, orange-fleshed cultivar that is grown globally and is the highest storage root yielder with a potential for early harvest relative to the other cultivars used in the study (Table 1). MU and OK are white- and purple-fleshed cultivars, respectively, with contrasting yield potential (Table 1). Virus-tested generation 1 storage roots were bedded in plastic containers containing soilless media (Sungro; Sun Gro Horticulture, Bellevue, WA) and served as a source 


\begin{tabular}{|c|c|c|c|c|c|}
\hline \multirow[b]{2}{*}{ Cultivar } & \multicolumn{3}{|c|}{ Storage root characteristics } & \multirow{2}{*}{$\begin{array}{l}\text { Relative U.S. No. } 1 \\
\text { yield potential }^{z}\end{array}$} & \multirow{2}{*}{$\begin{array}{l}\text { Cultivar release } \\
\text { information }\end{array}$} \\
\hline & Skin color & Flesh color & Shape & & \\
\hline Beauregard (BX) "B-14"y & Light rose & Orange & Elliptic & & Rolston et al. (1987) \\
\hline Murasaki (MU) & Dark purple & White with yellow cast & Elliptic to round & $\leq \overline{25} \%$ & LaBonte et al. (2008) \\
\hline Okinawan $(\mathrm{OK})^{\mathrm{x}}$ & Tan & Purple & Tapered, lobed & $<75 \%$ & \\
\hline
\end{tabular}

of transplants or vegetative cuttings for subsequent experiments. Baseline mineral leaf tissue of the source plants are shown in Supplemental Table 1. In each experiment, cuttings were set in 10-cm-diameter polyvinyl chloride (PVC) pots (height $=30 \mathrm{~cm}$ ) with detachable plastic bottoms. Each plastic bottom had five drain holes (2 $\mathrm{mm}$ in diameter). In addition, each PVC pot had four rows of side drain holes (2 $\mathrm{mm}$ in diameter; $3 \mathrm{~cm}$ apart within row) that were located diametrically opposite each other. These side drain holes were added to help reduce the incidence of a perched water table (Bilderback and Fonteno, 1987). Washed river sand was used as a growth substrate for all experiments. The diameter of the sand particles varied from 0.05 to $0.9 \mathrm{~mm}$ with most $(83 \%)$ in the $0.2-$ to $0.9-\mathrm{mm}$ range. Nutrient analysis data for the base substrate used in the study (extractable $\mathrm{B}=0.5 \mathrm{mg} \cdot \mathrm{kg}^{-1}$ ) as well as substrate samples from experimental treatments are shown in Supplemental Table 2. In all experiments, vegetative terminal cuttings with the following characteristics were used: 25 to $30 \mathrm{~cm}$ in length, five to six fully opened leaves, $\approx 5 \mathrm{~mm}$ diameter at the basal cut, and with uniform distribution of nodes.

All pots were provided with $1 \mathrm{X}$ Hoagland's No. 1 solution modified to alter the B levels in the micronutrient stock solution (Hoagland and Arnon, 1950). Three B levels were used: 0.1 $\mathrm{mg} \cdot \mathrm{kg}^{-1}(0 \mathrm{~B}$; B was omitted in the nutrient medium, substrate $B=0.1 \mathrm{mg} \cdot \mathrm{kg}^{-1}$ as shown in Supplemental Table 1), $0.5 \mathrm{mg} \cdot \mathrm{kg}^{-1}$ (1XB; sufficient $\mathrm{B}$, control) and $1 \mathrm{mg} \cdot \mathrm{kg}^{-1}(2 \mathrm{XB}$, high $\mathrm{B})$. The $1 \mathrm{mg} \cdot \mathrm{kg}^{-1} \mathrm{~B}$ level was selected as the high $\mathrm{B}$ experimental treatment based on prior work (O'Sullivan et al., 1997). The published 1X Hoagland's No. 1 solution was considered the control treatment $(1 \mathrm{XB})$ and contained $0.5 \mathrm{mg} \cdot \mathrm{kg}^{-1}$ of $\mathrm{B}$. For the $0 \mathrm{~B}$ and $2 \mathrm{XB}$ experimental treatments, the micronutrient stock solution was modified so that the final working solution contained 0 and $1 \mathrm{mg} \cdot \mathrm{kg}^{-1} \mathrm{~B}$, respectively. During the critical establishment stage, defined as the appearance of ARs in the first 3 to $5 \mathrm{~d}$ (Villordon et al., 2009), $150 \mathrm{~mL}$ of the nutrient solution was provided daily. After establishment, $200 \mathrm{~mL}$ was provided every other day until the completion of the study. This is the equivalent to providing $25 \mathrm{~mm} \cdot \mathrm{ha}^{-1}$ of water with each application. Cuttings were planted to a uniform depth of $6 \mathrm{~cm}$ with two to three nodes under the growth substrate surface, depending on cultivar. All experiments were arranged as a randomized complete block repeated across planting dates. Unless otherwise indicated, there were four replicates in each experiment (one plant per pot $=$ one replicate). Plants were grown for $15 \mathrm{~d}$, after which nearintact root systems were collected. Leaf tissues (fourth, fifth, and sixth fully opened leaves) were sampled for leaf tissue analysis. Plant height measurements were taken using a ruler.

Growth substrate moisture was measured with $\mathrm{ECH} 2 \mathrm{O}$ soil moisture sensors inserted vertically at the 2- to 7-cm depth (Model EC5; Decagon Devices Inc., Pullman, WA). The moisture of the growth substrate ranged from $5 \%$ to $9 \%$ volumetric water content (VWC), where $\approx 50 \%$ of field capacity (FC) $=7 \%$ VWC. At saturation, the growth substrate typically ranges from $12 \%$ to $14 \%$ VWC (Villordon et al., 2012). The greenhouse temperature regimen for the first planting date (PD1) was $28^{\circ} \mathrm{C}(\mathrm{SD}=2.3)$ for $14 \mathrm{~h}$ (day) and $24^{\circ} \mathrm{C}(\mathrm{SD}$ $=3.3$ ) for $10 \mathrm{~h}$ (night). The relative humidity $(\mathrm{RH})$, measured hourly, averaged 59\% (SD = 13.4). The temperature regimen for the second planting date (PD2) was $31^{\circ} \mathrm{C}(\mathrm{SD}=2.2)$ for $14 \mathrm{~h}$ (day) and $27^{\circ} \mathrm{C}(\mathrm{SD}=2.7)$ for $10 \mathrm{~h}$ (night). The RH averaged 53\% (SD = 15.7). The temperature and RH were monitored at the canopy level using an integrated temperature and RH sensor (Model RHT; Decagon Devices Inc.). Supplementary lighting was provided using light-emitting diode grow lights (Lumigrow Inc., Emeryville, CA) for $14 \mathrm{~h}$ per day. Photosynthetic photon flux $(P P F)$ for PD1 ranged from 422 to $2731 \mathrm{mmol} \cdot \mathrm{m}^{-2} \cdot \mathrm{s}^{-1} ; P P F$ for $\mathrm{PD} 2$ ranged from 582 to $3770 \mathrm{mmol} \cdot \mathrm{m}^{-2} \cdot \mathrm{s}^{-1}$. $P P F$ was measured at the canopy level with a quantum sensor (Model QSO-S; Decagon Devices Inc.). These experimental approaches have been used to validate storage root initiation timing in $\mathrm{BX}$ (Villordon et al., 2009, 2012) and measuring root architecture responses to biotic and abiotic variables (Villordon and Clark, 2014, 2018; Villordon et al., 2012, 2013).

Root architecture measurements and anatomic sampling. At harvest, the detachable plastic bottoms were removed, and the pot was tilted and the growth substrate was gradually removed using a stream of water. The roots were then placed in water-filled trays and rinsed twice. The AR samples were stored in 50\% alcohol solution before scanning. Storage root formation was confirmed by verifying the onset of anomalous cambium development in representative BX adventitious root samples $\geq 2 \mathrm{~mm}$ in diameter (Villordon et al., 2020).

Measurement of root architectural attributes followed the procedures described in prior work (Villordon et al., 2020). Briefly, intact washed ARs were floated on waterproof trays and scanned using an Epson Perfection V850 Pro Photo Scanner (Epson Corporation, San Jose, CA). Image acquisition parameter was set to "high" accuracy (600 dpi; image size $\approx 18 \mathrm{MB}$ ), whereas analysis precision was set to "high."

In prior work using the cultivar BX, preset intervals were used to classify root classes (Villordon et al., 2012, 2013); however, the variation in complexity of root samples among cultivars and overlapping root thickness led to classification errors among root classes in the current study. Hence, the following modifications of prior approaches were adopted for this work. For purposes of this work, AR specimens with labeled sections in Fig. 1 were used to standardize terminologies and clarify specific root class categories and attributes measured. First, main or primary root (MR) length (Fig. 1A and B) was manually measured using the segmented line feature in ImageJ (Schneider et al., 2012). Second, total root length (TRL) was measured using RhizoVision Explorer (Seethepalli and York, 2020). Debris such as sand particles and loose root tissue were excluded from the analysis by turning on the filter for non-root objects in RhizoVision Explorer (size $=25$ pixels). Finally, lateral root (LR) length was calculated by subtracting the manual MR length measurements from TRL. A separate analysis was performed in RhizoVision Explorer to detect the length of MRL segments that were $\geq 3 \mathrm{~mm}$ to measure incidence of storage root (SR) swelling (Fig. 1A and B). An AR that failed to show evidence of anomalous cambium development is presented in Fig. 1C for comparison. Wilson and Lowe (1973) documented the onset of SR formation, defined as the appearance of anomalous cambium, in MR segments that were $1 \mathrm{~mm}$ in diameter or greater. In the present study, anomalous cambium was detected in BX segments with diameter $\geq 2 \mathrm{~mm}$ (data not shown).

Statistical analyses. Root length and counts were transformed using log 10 and square root transformation, respectively, to reduce heterogeneity of variance. The unbalanced data set was analyzed using SAS Proc Mixed (SAS 9.4; SAS Inc., Cary, NC). Fisher's least significant difference test at the $0.05 P$ level was used to test for statistical significance. There were no significant planting date and cultivar effects as well as cultivar by B level effect for all root attributes; hence, data were combined. The $\mathrm{R}$ package 

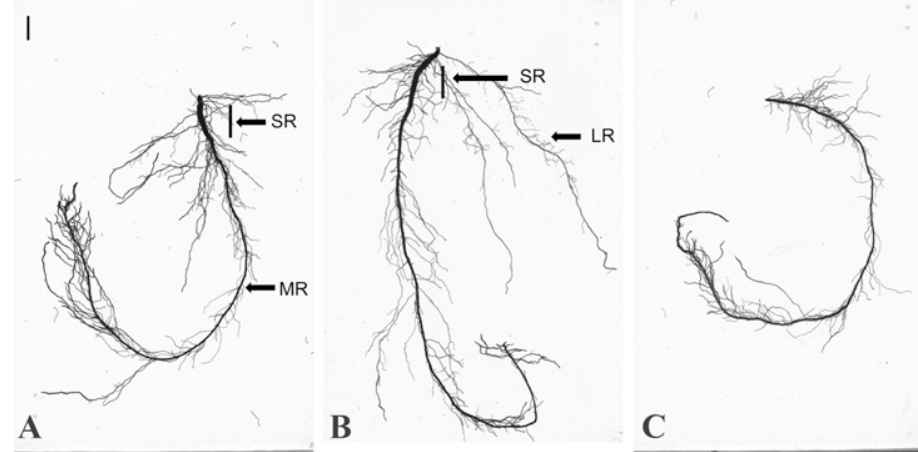

Fig. 1. Scanned images of 15-d-old 'Beauregard' adventitious roots labeled to clarify terminology as well as show evidence of storage root (SR) development. The main or primary root (MR) is labeled in A, along with a swollen section (SR) in the proximal 3- to 5-cm section associated with anomalous cambium activity. A representative lateral root (LR) is labeled in $\mathbf{B}$ along with another swollen section. An adventitious root with no evidence of swelling is shown in C. Scale bar $=1 \mathrm{~cm}(\mathbf{A})$. Adventitious roots were floated on waterproof trays and images were acquired using an Epson Perfection V850 Pro Photo Scanner (Epson Corporation).

ggplot2 (Wickham, 2009) was used to generate boxplots using R Studio (v.1.2.1335; R Studio Inc., Boston, MA) with $\mathrm{R}$ version 3.6 (R Development Core Team, 2019). The data presented were from nontransformed data. Pearson correlations among leaf tissue nutrient levels were calculated using 1000 bootstrapped correlations using the package boot in $\mathrm{R}$.

\section{Results and Discussion}

Boron leaf tissue levels and their effect on other mineral nutrients. Sufficient (1XB) and high $\mathrm{B}(2 \mathrm{XB})$ levels increased leaf tissue $\mathrm{B}$ in the check cultivar BX by $736 \%$ and $2269 \%$, respectively, relative to plants grown in low $\mathrm{B}$ (0B) (Table 2). Similar magnitudes were observed in cultivars MU and OK (Table 2). At $15 \mathrm{~d}$, leaf tissue toxicity symptoms were already visible in $\mathrm{BX}$ plants grown in $2 \mathrm{XB}$, that is, pale green to whitish interveinal chlorosis (O'Sullivan et al., 1997) as well as the onset of necrotic tissue (Supplemental Fig. 2B). Supplemental plantings showed that at 50 $\mathrm{d}$, necrosis progressed and premature leaf loss of older leaves was observed in BX (Supplemental Fig. 1C). These symptoms are consistent with $B$ toxicity responses and distribution reported in other species, with B accumulating at the end of the transpiration stream (reviewed in Nable et al., 1997). The cultivar OK grown in $2 \mathrm{XB}$ showed relatively lower B $\left(176 \pm 39 \mathrm{mg} \cdot \mathrm{kg}^{-1}\right)$ levels relative to BX $\left(363 \pm 17 \mathrm{mg} \cdot \mathrm{kg}^{-1}\right)$ and MU $(364 \pm 35$ $\mathrm{mg} \cdot \mathrm{kg}^{-1}$ ) grown with similar B levels. B tolerant cultivars are characterized by a decreased $\mathrm{B}$ in leaf tissues under high $\mathrm{B}$ conditions in comparison with nontolerant cultivars (Nable et al., 1990). Follow-up work is needed to generate more data to support this hypothesis and its applicability to sweetpotato cultivars with similar responses to OK. Mills and Jones (1996) previously reported that leaf tissue was considered sufficient when B levels ranged from 25 to $75 \mathrm{mg} \cdot \mathrm{kg}^{-1}$ at the midseason stage ( $\approx 60 \mathrm{~d}$ ). Scott and Bouwkamp (1974) reported a range of 49 to $51 \mathrm{mg} \cdot \mathrm{kg}^{-1}$ at $60 \mathrm{~d}$ in fieldgrown sweetpotato cultivars Centennial, Jewel, Nemagold, and Redmar grown with recommended practices. Schultheis and Campbell (1996) reported excessive B levels in leaf tissue $\left(>200 \mathrm{mg} \cdot \mathrm{kg}^{-1}\right)$ in field-grown sweetpotato cultivar 'Hernandez' when application levels exceeded $2.2 \mathrm{~kg} \cdot \mathrm{ha}^{-1}$. It is important to note that in the current study, a continuous supply of $1 \mathrm{mg} \cdot \mathrm{kg}^{-1} \mathrm{~B}$ was provided during the study period for the $2 \mathrm{XB}$ experimental treatment. In field conditions, roots gradually deplete nutrients in the root zone, leading to the formation of depletion zones (De Parseval et al., 2017). However, B is relatively mobile in the soil (Flis, 2019) such that rainfall or irrigation events may replenish the depletion zone.

Current available data support the hypothesis that B deficiency, sufficiency, and toxicity exert effects on other mineral nutrients in the plant, but the data are conflicting (reviewed in Bariya et al., 2014). The conflicting results may be due in part to different experimental systems and cultivar-specific B requirements such that specific $B$ effects may vary under B sufficient and deficient conditions (reviewed in Bariya et al., 2014). These trends are consistent with the findings from the current study. When the correlation analysis was performed on the total data set, we failed to detect significant correlations between $\mathrm{B}$ and other mineral nutrients. However, when data from $0 \mathrm{~B}$-treated plants were removed from the data set, significant correlations were observed between $\mathrm{B}$ and the following: $\mathrm{Ca}(0.63, P<0.001), \mathrm{Mg}(0.70, P<$ $0.001), \mathrm{Zn}(-0.4, P=0.04)$, and $\mathrm{Cu}(-0.45$, $P=0.02$ ) (Fig. 2). Steinburg et al. (1955) reported similar conflicting results when analysis was performed separately on tobacco plants provisioned with $\mathrm{B}$ relative to plants without B. Francois (1986) reported that increasing $\mathrm{B}$ in the soil solution increased the concentration of $\mathrm{B}, \mathrm{P}, \mathrm{K}$, and $\mathrm{Mg}$ in tomato leaves, whereas $\mathrm{Ca}$ and $\mathrm{Na}$ showed inconsistent trends. The negative correlation of $\mathrm{B}$ with $\mathrm{Zn}$ and $\mathrm{Cu}$ observed in the current work is consistent with findings reported by Leece (1978), although in the same report, Ca was negatively correlated. The negative correlation with $\mathrm{Zn}$ is consistent with available evidence that supports the hypothesis that $\mathrm{Zn}$ interferes with the absorption of $\mathrm{Fe}$ and $\mathrm{B}$ in plants and that the application of $\mathrm{Zn}$ is suggested as a measure to alleviate B toxicity in crops grown in B-rich soil (reviewed in Prasad et al., 2016). Husseini et al. (2007) and Aref (2011) suggested that B and $\mathrm{Zn}$ are antagonistic with respect to their concentration in plant tissue. However, Sinha et al. (2000) reported contrary results and observed a positive relationship between $\mathrm{Zn}$ and $\mathrm{B}$.

Table 2. Leaf tissue nutrient concentrations in three sweetpotato cultivars as affected by boron level. ${ }^{\mathrm{z}}$

\begin{tabular}{|c|c|c|c|c|c|c|c|c|c|}
\hline \multirow[b]{2}{*}{ Nutrient } & \multicolumn{3}{|c|}{ Beauregard } & \multicolumn{3}{|c|}{ Murasaki } & \multicolumn{3}{|c|}{ Okinawa } \\
\hline & 0B & $1 \mathrm{XB}$ & $2 \mathrm{XB}$ & 0B & $1 \mathrm{XB}$ & $2 \mathrm{XB}$ & 0B & $1 \mathrm{XB}$ & $2 \mathrm{XB}$ \\
\hline $\mathrm{B}, \mathrm{mg} \cdot \mathrm{kg}^{-1}$ & $15 \pm 1 \mathrm{e}$ & $128 \pm 19 \mathrm{c}$ & $363 \pm 17 a$ & $15 \pm 4 \mathrm{e}$ & $104 \pm 12 \mathrm{~cd}$ & $364 \pm 35 a$ & $14 \pm 2 \mathrm{e}$ & $80 \pm 10$ e & $176 \pm 39 \mathrm{~b}$ \\
\hline $\mathrm{N}, \%$ & $5.1 \pm 0.1 \mathrm{ab}$ & $5.1 \pm 0.3$ & $5.1 \pm 0.4$ & $5.1 \pm 0.2$ & $5.2 \pm 0.2$ & $5.3 \pm 0.1$ & $4.8 \pm 0.1$ & $5.1 \pm 0.3$ & $4.7 \pm 0.3$ \\
\hline $\mathrm{P}, \%$ & $0.3 \pm 0.01 \mathrm{a}$ & $0.3 \pm 0.04 \mathrm{a}$ & $0.3 \pm 0.01 \mathrm{a}$ & $0.3 \pm 0.1 \mathrm{a}$ & $0.3 \pm 0.03 \mathrm{a}$ & $0.3 \pm 0.07 \mathrm{a}$ & $0.3 \pm 0.04 \mathrm{a}$ & $0.3 \pm 0.01 \mathrm{a}$ & $0.3 \pm 0.05 \mathrm{a}$ \\
\hline $\mathrm{K}, \%$ & $5.3 \pm 0.5 \mathrm{a}$ & $5.2 \pm 0.8 \mathrm{a}$ & $5.1 \pm 0.5 \mathrm{a}$ & $4.8 \pm 0.3 \mathrm{a}$ & $5.1 \pm 0.5 \mathrm{a}$ & $5.1 \pm 0.2 \mathrm{a}$ & $5.2 \pm 0.8 \mathrm{a}$ & $5.6 \pm 0.5 \mathrm{a}$ & $4.9 \pm 0.9 \mathrm{a}$ \\
\hline $\mathrm{Ca}, \%$ & $2.2 \pm 0.1 \mathrm{a}$ & $2.2 \pm 0.2 \mathrm{ab}$ & $2.1 \pm 0.1 \mathrm{abc}$ & $1.6 \pm 0.2 \mathrm{~cd}$ & $1.7 \pm 0.1 \mathrm{~cd}$ & $1.7 \pm 0.1 \mathrm{bcd}$ & $1.4 \pm 0.2 \mathrm{~d}$ & $1.5 \pm 0.2 \mathrm{~d}$ & $1.5 \pm 0.3 \mathrm{~d}$ \\
\hline $\mathrm{Mg}, \%$ & $0.8 \pm 0.04 \mathrm{a}$ & $0.8 \pm 0.07 \mathrm{a}$ & $0.8 \pm 0.02 \mathrm{ab}$ & $0.6 \pm 0.1 \mathrm{bc}$ & $0.7 \pm 0.07 \mathrm{ab}$ & $0.8 \pm 0.04 \mathrm{ab}$ & $0.5 \pm 0.1 \mathrm{~cd}$ & $0.5 \pm 0.07 \mathrm{~d}$ & $0.5 \pm 0.1 \mathrm{~d}$ \\
\hline $\mathrm{S}, \%$ & $0.4 \pm 0.02 \mathrm{ab}$ & $0.5 \pm 0.09 \mathrm{a}$ & $0.4 \pm 0.05 \mathrm{ab}$ & $0.35 \pm 0.1 \mathrm{~b}$ & $0.3 \pm 0.03 \mathrm{~b}$ & $0.3 \pm 0.02 \mathrm{~b}$ & $0.4 \pm 0.08 \mathrm{ab}$ & $0.4 \pm 0.04 \mathrm{~b}$ & $0.3 \pm 0.03 b$ \\
\hline $\mathrm{Fe}, \mathrm{mg} \cdot \mathrm{kg}^{-1}$ & $140 \pm 23 \mathrm{a}$ & $132 \pm 30 \mathrm{a}$ & $136 \pm 20 \mathrm{a}$ & $104 \pm 13 \mathrm{a}$ & $119 \pm 4 \mathrm{a}$ & $116 \pm 3 \mathrm{a}$ & $123 \pm 31 \mathrm{a}$ & $100 \pm 16 \mathrm{a}$ & $118 \pm 19 \mathrm{a}$ \\
\hline $\mathrm{Mn}, \mathrm{mg} \cdot \mathrm{kg}^{-1}$ & $197 \pm 16 \mathrm{ab}$ & $202 \pm 4 \mathrm{a}$ & $171 \pm 4 \mathrm{bc}$ & $167 \pm 6 \mathrm{bc}$ & $166 \pm 4 \mathrm{bc}$ & $161 \pm 15 \mathrm{c}$ & $143 \pm 28 \mathrm{~cd}$ & $120 \pm 25 \mathrm{de}$ & $111 \pm 7 \mathrm{e}$ \\
\hline $\mathrm{Al}, \mathrm{mg} \cdot \mathrm{kg}^{-1}$ & $21 \pm 17 \mathrm{a}$ & $21 \pm 18 \mathrm{a}$ & $12 \pm 2 \mathrm{a}$ & $14 \pm 4 \mathrm{a}$ & $15 \pm 3 \mathrm{a}$ & $15 \pm 2 \mathrm{a}$ & $24 \pm 13 \mathrm{a}$ & $13 \pm 3 \mathrm{a}$ & $12 \pm 3 \mathrm{a}$ \\
\hline $\mathrm{Zn}, \mathrm{mg} \cdot \mathrm{kg}^{-1}$ & $16.7 \pm 2 \mathrm{~d}$ & $17.7 \pm 3 \mathrm{~cd}$ & $16.7 \pm 2 \mathrm{~d}$ & $20.7 \pm 1 \mathrm{~cd}$ & $21 \pm 2 \mathrm{bcd}$ & $22 \pm 1 \mathrm{bc}$ & $25 \pm 3 \mathrm{ab}$ & $21 \pm 3 \mathrm{bcd}$ & $30 \pm 2 a$ \\
\hline
\end{tabular}

${ }^{\mathrm{z}}$ Values represent means ( $\pm \mathrm{SE}$ ). Means within rows followed by a common letter are not significantly different based on Fisher's least significant different means separation test $(P \leq 0.05)$. Values were $\log _{10}$ transformed. Corresponding nontransformed values are shown. Leaf tissue samples were collected $15 \mathrm{~d}$ after planting. $\mathrm{OB}=\mathrm{B}$ was omitted in the nutrient solution, substrate $\mathrm{B}=0.1 \mathrm{mg} \cdot \mathrm{kg}^{-1} ; 1 \mathrm{XB}^{-1}=0.5 \mathrm{mg} \cdot \mathrm{kg}^{-1} ; 2 \mathrm{XB}=1 \mathrm{mg} \cdot \mathrm{kg}^{-1}$. 


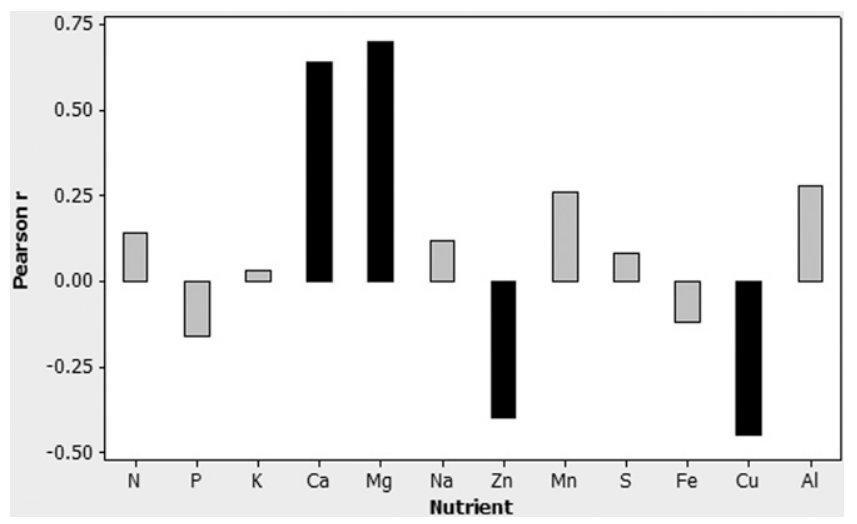

Fig. 2. Bootstrapped correlation values between boron and other macro- and micronutrients in sweetpotato leaf tissue. Solid black bars represent significant correlations at the $P<0.05$ confidence level. Leaf tissue mineral nutrient data were combined from three cultivars and two planting dates. Leaf tissue samples were collected $15 \mathrm{~d}$ after planting. about the influence of $\mathrm{B}$ on other mineral nutrients in plants. In sweetpotato, it is evident dardized growth and experimental conditions.

$S R$ formation timing. The check cultivar $0 \mathrm{~B}$ and $1 \mathrm{XB}$ treatments but not in $2 \mathrm{XB}$ at $15 \mathrm{~d}$ (Figs. 1A and 3). Supplemental plantings that were harvested at $50 \mathrm{~d}$ showed evidence of SRs in 2XB treated plants (Supplemental Fig. 1B), supporting the hypothesis that the high B level used in this study did not suppress, but only delayed SR formation. The early onset of SR formation in BX relative to other cultivars is consistent with past findings in which SR formation was detected at 15 to $20 \mathrm{~d}$ in BX in similar growing conditions (Villordon and Clark, 2018; Villordon et al., 2009, 2020). Among the cultivars used in the current study, BX consistently produces relatively higher SR

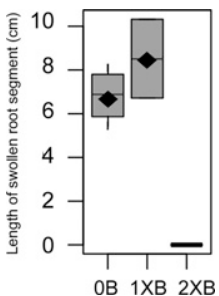

Fig. 3. Box plots of main root segments with diameter $\geq 2 \mathrm{~mm}$ in the check sweetpotato cultivar 'Beauregard' (BX) grown in three boron levels. Boxes represent the interquartile range (IQR, or middle $50 \%$ ) of values for each feature. Shaded diamonds represent mean values. Bold horizontal lines indicate median values. Upper box plot whiskers represent the last data point within the range of $75 \%$ quantile + 1.5 IQR, lower box plot whiskers represent the last data point within the range of $25 \%$ quantile - 1.5 IQR. Mean comparisons were performed on transformed data; corresponding nontransformed values are shown. Boxes with different letters differ significantly at the $5 \%$ level by Fisher's least significant difference. Boron levels: $0 \mathrm{~B}=$ $\mathrm{B}$ was omitted in the nutrient solution, substrate $\mathrm{B}=0.1 \mathrm{mg} \cdot \mathrm{kg}^{-1} ; 1 \mathrm{XB}=0.5 \mathrm{mg} \cdot \mathrm{kg}^{-1} ; 2 \mathrm{XB}=1$ $\mathrm{mg} \cdot \mathrm{kg}^{-1}$. Data were combined from two planting dates; adventitious roots were sampled at $15 \mathrm{~d}$.
There are other various conflicting findings that follow-up studies are needed with stan$\mathrm{BX}$ presented evidence of SR formation in the yields in multiyear and multilocation field trials (Table 1; LaBonte et al., 2013). These data corroborate observations that early SR formation is an indicator of relative productivity in sweetpotato cultivars (Firon et al., 2013). Prior evidence shows that B leaf tissue concentrations exceeding $400 \mathrm{mg} \cdot \mathrm{kg}^{-1}$ are associated with $30 \%$ to $50 \%$ growth reductions (Ayers and Westcot, 1989). Sweetpotato has been previously classified as semitolerant to high B levels $\left(2 \mathrm{mg} \cdot \mathrm{kg}^{-1}\right)$ in irrigation water (Ayers and Westcot, 1989); However, there is no current available data on the role of B on sweetpotato SR yield in field conditions.

AR number. We failed to detect differences in AR number within cultivars and across $B$ levels but OK showed 25\% less AR number relative to BX across all $\mathrm{B}$ levels (Fig. 4). AR number variation at the onset of SR formation among sweetpotato cultivars has also been reported previously (Lowe and Wilson, 1974;
Nakatani and Watanabe, 1986). The requirement for B in the growth of ARs formed on stem cuttings was first demonstrated by Hemberg (1951) and subsequently reported in cuttings of other plant species such as sunflower (Helianthus annuus) (Josten and Kutschera, 1999) and mung bean (Phaseolus aureus) (Jarvis et al., 1983). In sweetpotato, the presence of $\mathrm{B}$ in the substrate does not appear to be a requirement for AR emergence. Evidence from prior work (Lowe and Wilson, 1974; Ma et al., 2015) indicates that there is no direct correlation between total ARs per plant and final SR number at harvest. Lowe and Wilson (1974) cited limiting factors that influenced final SR yield, including assimilate production and transport.

There is evidence from other plant species that ethylene mediates variation in AR number response. We have previously documented that cultivar-specific AR emergence is mediated by differential ethylene sensitivity in cultivars (Villordon et al., 2012); however, there is very limited information about specific ethylene effects in sweetpotato RSA and storage root formation in general.

$M R$ length. The $0 \mathrm{~B}$ treatment was associated with $20 \%$ and $48 \%$ reduction in main root (MR) length in BX and OK, respectively, relative to plants grown in $1 \mathrm{XB}$ and $2 \mathrm{XB}$ (Fig. 5). $2 \mathrm{XB}$ was associated with a $10 \%$ increase in MR length in MU relative to plants grown in $\mathrm{OB}$ and $1 \mathrm{XB}$. These results in part corroborate current findings as regards the association of $\mathrm{B}$ deficiency with primary or MR length reduction in other species including mung bean (Middleton et al., 1978), squash (Cucurbita pepo) (Lukaszewski and Blevins, 1996), and wheat (Triticum aestivum) (Holloway and Alston, 1992). This growth arrest is due to a reduction in cell elongation and cell division at the growing tips, but the precise molecular mechanism is still under active investigation (reviewed in Matthes et al., 2020). Additional roles for B

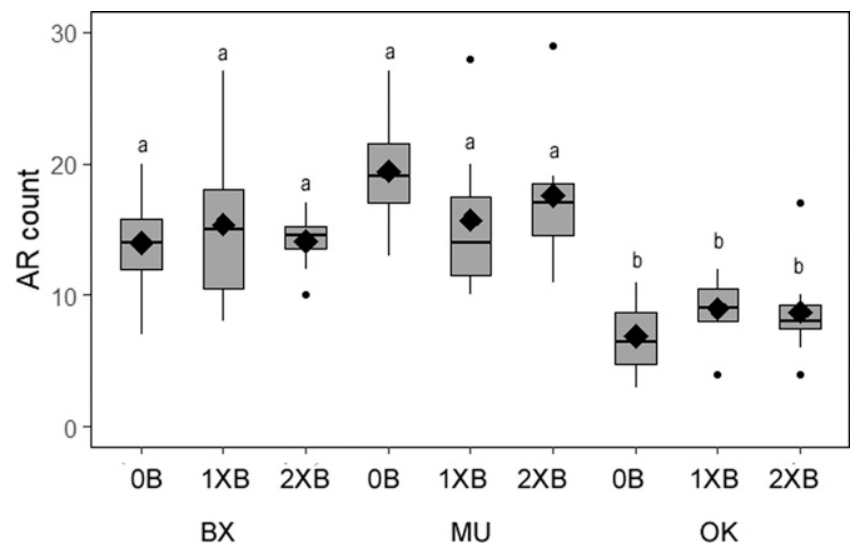

Fig. 4. Box plots of adventitious root (AR) number $\geq 2 \mathrm{~cm}$ in length of sweetpotato cultivars grown in three boron levels. Boxes represent the interquartile range (IQR, or middle 50\%) of values for each feature. Shaded diamonds represent mean values. Bold horizontal lines indicate median values. Upper box plot whiskers represent the last data point within the range of $75 \%$ quantile $+1.5 \mathrm{IQR}$, lower box plot whiskers represent the last data point within the range of $25 \%$ quantile $-1.5 \mathrm{IQR}$. Dots represent outliers (values smaller or larger than the median \pm 1.5 times the interquartile range). Mean comparisons were performed on transformed data; corresponding nontransformed values are shown. Boxes with different letters differ significantly at the $5 \%$ level by Fisher's least significant difference. Boron levels: $0 \mathrm{~B}=\mathrm{B}$ was omitted in the nutrient solution, substrate $\mathrm{B}=0.1 \mathrm{mg} \cdot \mathrm{kg}^{-1}$; $1 \mathrm{XB}=0.5 \mathrm{mg} \cdot \mathrm{kg}^{-1} ; 2 \mathrm{XB}=1 \mathrm{mg} \cdot \mathrm{kg}^{-1}$. Cultivars: $\mathrm{BX}=$ Beauregard; $\mathrm{MU}=$ Murasaki; $\mathrm{OK}=$ Okinawa. Data were combined from two planting dates; ARs were sampled at $15 \mathrm{~d}$. 


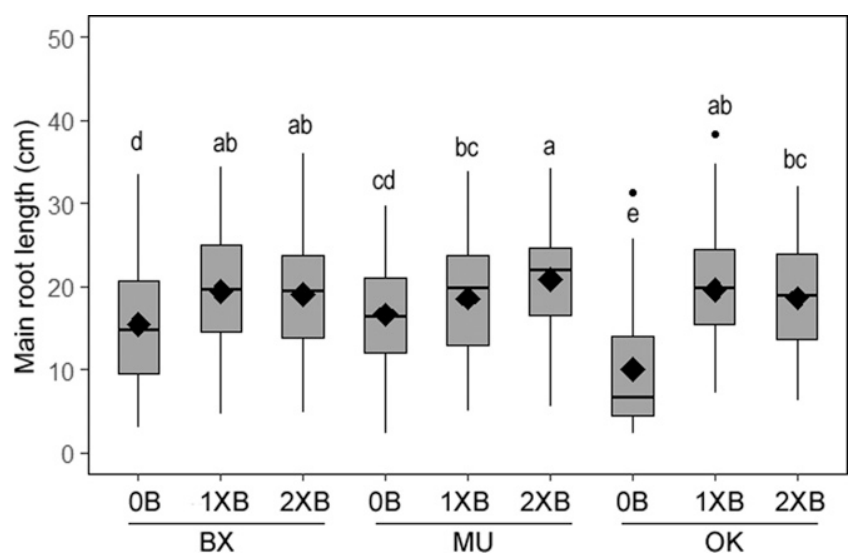

Fig. 5. Box plots of main root length of sweetpotato cultivars grown in three boron levels. Boxes represent the interquartile range (IQR, or middle $50 \%$ ) of values for each feature. Shaded diamonds represent mean values. Bold horizontal lines indicate median values. Upper box plot whiskers represent the last data point within the range of $75 \%$ quantile $+1.5 \mathrm{IQR}$, lower box plot whiskers represent the last data point within the range of $25 \%$ quantile -1.5 IQR. Dots represent outliers (values smaller or larger than the median \pm 1.5 times the IQR). Mean comparisons were performed on transformed data; corresponding nontransformed values are shown. Boxes with different letters differ significantly at the $5 \%$ level by Fisher's least significant difference. Boron levels: $0 \mathrm{~B}=\mathrm{B}$ was omitted in the nutrient solution, substrate $\mathrm{B}=0.1 \mathrm{mg} \cdot \mathrm{kg}^{-1} ; 1 \mathrm{XB}=0.5 \mathrm{mg} \cdot \mathrm{kg}^{-1} ; 2 \mathrm{XB}=1$ $\mathrm{mg} \cdot \mathrm{kg}^{-1}$. Cultivars: $\mathrm{BX}=$ Beauregard; $\mathrm{MU}=$ Murasaki; $\mathrm{OK}=$ Okinawa. Data were combined from two planting dates; adventitious roots were sampled at $15 \mathrm{~d}$.

have been proposed and demonstrated related to metabolism, membrane processes, and phytohormone signaling, although it is difficult to separate primary and secondary effects of B deficiency (reviewed in Matthes et al., 2020). In sweetpotato, knowledge of variables that affect MRL is of practical importance because this contributes to the understanding of the determination of SR shape. length (Fig. 6) and count (Fig. 7) in all cultivars, but the magnitude of responses varied with cultivars. For example, in the check cultivar $\mathrm{BX}, 0 \mathrm{~B}$ was associated with a $32 \%$ reduction in $\mathrm{LR}$ length relative to $1 \mathrm{XB}$;
LR length and count. Low B reduced LR

however, increasing B to $2 \mathrm{XB}$ did not lead to further LR length increase. In contrast, MU showed a $60 \%$ increase in LR growth when $\mathrm{B}$ was increased from $0 \mathrm{~B}$ to $2 \mathrm{XB}$. The cultivar $\mathrm{OK}$ showed similar significant increases in LR length with $1 \mathrm{XB}$ and $2 \mathrm{XB}$ relative to plants grown in $0 \mathrm{~B}$. Relative to $\mathrm{BX}$ and $\mathrm{MU}$, the cultivar $\mathrm{OK}$ had the longest $\mathrm{LR}$ at $1 \mathrm{XB}$ and $2 \mathrm{XB}$. Similar trends were observed with LR counts. These results are consistent with current evidence supporting the hypothesis that B deficiency is associated with reduced root growth but the response varies with genotype, for example in Citrus (Mei et al., 2011). In general, B deficiency is associated

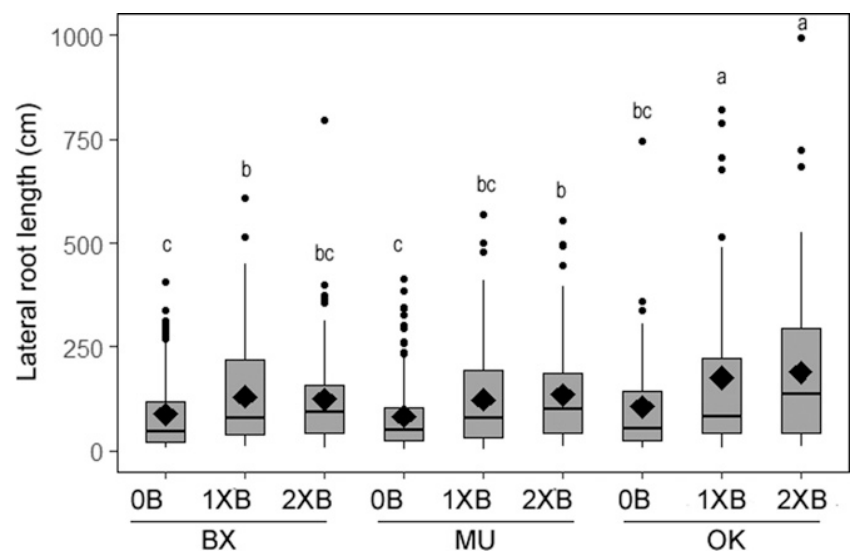

Fig. 6. Box plots of lateral root length of sweetpotato cultivars grown in three boron levels. Boxes represent the interquartile range (IQR, or middle $50 \%$ ) of values for each feature. Shaded diamonds represent mean values. Bold horizontal lines indicate median values. Upper box plot whiskers represent the last data point within the range of $75 \%$ quantile $+1.5 \mathrm{IQR}$, lower box plot whiskers represent the last data point within the range of $25 \%$ quantile -1.5 IQR. Dots represent outliers (values smaller or larger than the median \pm 1.5 times the interquartile range). Mean comparisons were performed on transformed data; corresponding nontransformed values are shown. Boxes with different letters differ significantly at the $5 \%$ level by Fisher's least significant difference. Boron levels: $0 \mathrm{~B}=$ $\mathrm{B}$ was omitted in the nutrient solution, substrate $\mathrm{B}=0.1 \mathrm{mg} \cdot \mathrm{kg}^{-1} ; 1 \mathrm{XB}=0.5 \mathrm{mg} \cdot \mathrm{kg}^{-1} ; 2 \mathrm{XB}=1$ $\mathrm{mg} \cdot \mathrm{kg}^{-1}$. Cultivars: $\mathrm{BX}=$ Beauregard; $\mathrm{MU}=$ Murasaki; $\mathrm{OK}=$ Okinawa. Data were combined from two planting dates; adventitious roots were sampled at $15 \mathrm{~d}$. with reduction in root systems as documented in melons (Cucumis melo) (Edelstein et al., 2007). Kouchi and Kumazawa (1975) reported that the primary effect of B deficiency was the rapid cessation of root elongation followed by browning and some morphological changes in the root tips, such as abnormal enlargement and dense appearance of LRs. We observed browning and necrosis of OK LR tips sampled from plants grown with 0B (Supplemental Fig. 2A). We failed to detect plant height differences within cultivars during the 15-d study period in our experimental conditions (Supplemental Fig. 3). This is consistent with observations in other species that the root system is more sensitive to B deficiency than shoots (reviewed in Brdar-Jokanović, 2020); however, it is conceivable that B deficiency may limit vine growth during the rapid bulking of SRs in field conditions, typically starting at 50 to $60 \mathrm{~d}$ with the remobilization of nutrients from the shoots to the developing SRs (Scott and Bouwkamp, 1974).

Knowledge about plant adaptation to B availability will lead to the optimization of $B$ management approaches and selection of resilient cultivars that can tolerate the narrow range of B deficiency and toxicity. In general, the findings from the current study corroborate cumulative evidence from other species that B deficiency is associated with reduced root growth. Second, the results are consistent with current understanding of the relative narrow range and crop species specificity of B effectivity. Third, the results are consistent with the hypothesis that $\mathrm{B}$ response varies with cultivar. Currently, there are no specific published recommendations for $\mathrm{B}$ management for commercially grown sweetpotato cultivars and represents a significant gap in B management knowledge in sweetpotato. Our work represents an initial step toward an indepth understanding of the role of $B$ in sweetpotato productivity as well as provides some baseline information for follow-up studies on developing specific recommendations for managing $\mathrm{B}$ in sweetpotato production to address low soil $\mathrm{B}$ conditions and to minimize the risk of overapplication. This work as well as current available data indicate that for commercial sweetpotato production, a best practices approach for B management should include soil B measurements in soil testing to determine if any B applications are necessary as well as account for any B presence in other fertilizer materials that will be applied. Currently, B is not included in routine soil analysis (McAuley et al., 2016). In sweetpotato, B remobilization from shoots to roots, as documented by Scott and Bouwkamp (1974), is another variable that can modulate sweetpotato response to low B. Prior work has shown that B is remobilized and transported into plant tops, whereas a small but adequate amount was remobilized and transported to the roots (Oertli, 1993). Follow-up studies might include the role of B status of planting materials and how this interacts with soil B availability. 


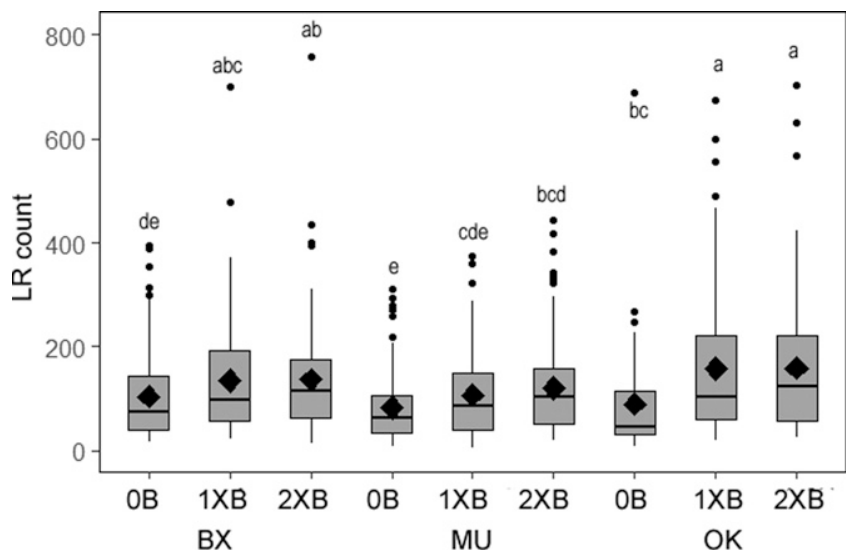

Fig. 7. Box plots of lateral root number of sweetpotato cultivars grown in three boron levels. Boxes represent the interquartile range (IQR, or middle $50 \%$ ) of values for each feature. Shaded diamonds represent mean values. Bold horizontal lines indicate median values. Upper box plot whiskers represent the last data point within the range of $75 \%$ quantile $+1.5 \mathrm{IQR}$, lower box plot whiskers represent the last data point within the range of $25 \%$ quantile-1.5 IQR. Dots represent outliers (values smaller or larger than the median \pm 1.5 times the interquartile range). Mean comparisons were performed on transformed data; corresponding nontransformed values are shown. Boxes with different letters differ significantly at the $5 \%$ level by Fisher's least significant difference. Boron levels: $0 \mathrm{~B}=$ $\mathrm{B}$ was omitted in the nutrient solution, substrate $\mathrm{B}=0.1 \mathrm{mg} \cdot \mathrm{kg}^{-1} ; 1 \mathrm{XB}=0.5 \mathrm{mg} \cdot \mathrm{kg}^{-1} ; 2 \mathrm{XB}=1$ $\mathrm{mg} \cdot \mathrm{kg}^{-1}$. Cultivars: $\mathrm{BX}=$ Beauregard; $\mathrm{MU}=$ Murasaki; $\mathrm{OK}=$ Okinawa. Data were combined from two planting dates; adventitious roots were sampled at $15 \mathrm{~d}$.

\section{Conclusion}

Although some of the findings corroborate data from model plant species, significant gaps exist in understanding sweetpotato response to B deficient and toxic conditions, especially during the critical storage root formation phase. The experimental data support the hypothesis that sweetpotato cultivars vary in response to low and excessive B and that low B generally reduces overall root mass. Follow-up studies with more diverse materials are needed, including the measurement of transpiration steam to help explain the differential B uptake among cultivars. Even in model systems, significant gaps exist in knowledge about plant responses to deficient and toxic B levels.

\section{Literature Cited}

Aref, F. 2011. The effect of boron and zinc application on concentration and uptake of nitrogen, phosphorus and potassium uptake in corn grain. Indian J. Sci. Technol. 4:785-791, https://doi. org/10.17485/ijst.

Ayers, R.S. and D.W. Westcot. 1989. Water quality for agriculture. FAO Irrig. Drain. Pap. 29: 737-746.

Bariya, H., S. Bagtharia, and A. Patel. 2014. Boron: A promising nutrient for increasing growth and yield of plants, p. 153-170. In: M.J. Hawkesford, S. Kopriva, and L.J. De Kok (eds.). Nutrient use efficiency in plants. Springer International Publishing, Besel, Switzerland, https://doi.org/ 10.1007/978-3-319-10635-9_6.

Bilderback, T.E. and W.C. Fonteno. 1987. Effects of container geometry and media physical properties on air and water volumes in containers. J. Environ. Hort. 5:180-182, https://doi. org/10.24266/0738-2898-5.4.180.

Brdar-Jokanović, M. 2020. Boron toxicity and deficiency in agricultural plants. Intl. J. Mol. Sci. 21:1424, https://doi.org/10.3390/ijms21041424.
Byju, G., M. Nedunchezhiyan, and S.K. Naskar. 2007. Sweet potato response to boron application on an alfisols in the subhumid tropical climate of India. Commun. Soil Sci. Plant Anal. 38:23472356, https://doi.org/10.1080/00103620701588 460.

De Parseval, H., S. Barot, J. Gignoux, J.C. Lata, and X. Raynaud. 2017. Modelling facilitation or competition within a root system: Importance of the overlap of root depletion and accumulation zones. Plant Soil 419:97-111, https:// doi.org/10.1007/s11104-017-3321-y.

Edelstein, M., M. Ben-Hur, and Z. Plaut. 2007. Grafted melons irrigated with fresh or effluent water tolerate excess boron. J. Amer. Soc. Hort. Sci. 132: 484-491, https://doi.org/10.21273/JASHS.132.4. 484.

Fageria, V.D. 2001. Nutrient interactions in crop plants. J. Plant Nutr. 24:1269-1290, https://doi. org/10.1081/PLN-100106981.

Flis, S. 2019. 4R decisions for boron fertilization. Crops Soils. 52:10-41, https://doi.org/10.2134/ cs2019.52.0105.

Firon, N., D. LaBonte, A. Villordon, Y. Kfir, J. Solis, E. Lapis, T.S. Perlman, A. Doron-Faigenboim, A. Hetzroni, L. Althan, and L.A. Nadir. 2013. Transcriptional profiling of sweetpotato (Ipomoea batatas) roots indicates down-regulation of lignin biosynthesis and up-regulation of starch biosynthesis at an early stage of storage root formation. BMC Genomics 14:460, https:// doi.org/10.1186/1471-2164-14-460.

Francois, L.E. 1986. Effect of excess boron on broccoli, cauliflower and radish. J. Amer. Soc. Hort. Sci. 111:494-498.

Goldberg, S. 1997. Reactions of boron with soils. Plant Soil 193:35-48, https://doi.org/10.1023/ A:1004203723343.

Giehl, R.F., B.D. Gruber, and N. von Wirén. 2014. It's time to make changes: Modulation of root system architecture by nutrient signals. J. Expt. Bot. 65:769-778, https://doi.org/10.1093/jxb/ ert421.

Hemberg, T. 1951. Rooting experiments with hypocotyles of Phaseolus vulgaris L. Physiol. Plant.
4:358-369, https://doi.org/10.1111/j.1399-3054. 1951.tb07523.x.

Hoagland, D.R. and D.I. Arnon. 1950. The waterculture method for growing plants without soil. Circular. California Agricultural Experiment Station, 347 (2nd ed.).

Holloway, R.E. and A.M. Alston. 1992. The effects of salt and boron on growth of wheat. Aust. J. Agr. Res. 43:987-1001, https://doi.org/ 10.1071/AR9920987.

Husseini, M., M. Maftoun, N. Karimian, A. Ronaghie, and Y. Eman. 2007. Effect of zinc $x$ boron interaction on plant growth and tissue nutrient concentration. J. Plant Nutr. 30:773-781, https:// doi.org/10.1080/01904160701289974.

Jarvis, B.C., A.H.N. Ali, and A.I. Shaheed. 1983. Auxin and boron in relation to the rooting response and ageing of mung bean cuttings. New Phytol. 95:509-518, https://doi.org/10.1111/j. 1469-8137.1983.tb03516.x.

Josten, P. and U. Kutschera. 1999. The micronutrient boron causes the development of adventitious roots in sunflower cuttings. Ann. Bot. 84:337342, https://doi.org/10.1006/anbo.1999.0922.

Kouchi, H. and K. Kumazawa. 1975. Anatomical responses of root tips to boron deficiency I. Effects of boron deficiency on elongation of root tips and their morphological characteristics. Soil Sci. Plant Nutr. 21:21-28, https://doi. org/10.1080/00380768.1975.10432617.

LaBonte, D., C. Clark, M. Hoy, A. Villordon, J. Cannon, M. Sistrunk, E. Freeman, and G. Roberts. 2004. Yield of four generations of virustested sweetpotato. HortTechnology 14:320 322, https://doi.org/10.21273/HORTTECH.14. 3.0320 .

LaBonte, D.R., A.Q. Villordon, C.A. Clark, P.W Wilson, and C.S. Stoddard. 2008. 'Murasaki29' sweetpotato. HortScience 43:1895-1896, https://doi.org/10.21273/HORTSCI.43.6.1895.

LaBonte, D., A. Villordon, T. Smith, and C. Clark. 2013. Sweetpotato plant named '07-146'. USA Patent USPP23785. July 30

Leece, D.R. 1978. Effects of boron on the physiological activity of zinc in maize. Aust. J. Agr. Res. 29:739-749, https://doi.org/10.1071/AR97 80739.

Lowe, S.B. and L.A. Wilson. 1974. Comparative analysis of tuber development in six sweet potato (Ipomoea batatas (L.) Lam) cultivars: 1. Tuber initiation, tuber growth and partition of assimilate. Ann. Bot. 38:307-317, https://doi. org/10.1093/oxfordjournals.aob.a084814.

Lukaszewski, K.M. and D.B. Blevins. 1996. Root growth inhibition in boron-deficient or aluminum-stressed squash may be a result of impaired ascorbate metabolism. Plant Physiol. 112:11351140, https://doi.org/10.1104/pp.112.3.1135.

Ma, J., R. Aloni, A. Villordon, D. LaBonte, Y. Kfir, H. Zemach, A. Schwartz, L. Althan, and N. Firon. 2015. Adventitious root primordia formation and development in stem nodes of 'Georgia Jet' sweetpotato, Ipomoea batatas. Amer. J. Bot. 102:1040-1049, https://doi.org/10.3732/ajb.14 00505

Matthes, M.S., J.M. Robil, and P. McSteen. 2020. From element to development: The power of the essential micronutrient boron to shape morphological processes in plants. J. Expt. Bot. 71: 1681-1693, https://doi.org/10.1093/jxb/eraa042.

McAuley, C., A. Dersch, L.N. Kates, D.R. Sowan, and C.A. Ollson. 2016. Improving risk assessment calculations for traditional foods through collaborative research with First Nations communities. Risk Anal. 36:2195-2207, https://doi. org/10.1111/risa.12578.

Mei, L., O. Sheng, S.A. Peng, G.F. Zhou, Q.J. Wei, and Q.H. Li. 2011. Growth, root morphology 
and boron uptake by citrus rootstock seedlings differing in boron-deficiency responses. Scientia Hort. 129:426-432, https://doi.org/10.1016/j. scienta.2011.04.012.

Middleton, W., B.C. Jarvis, and A. Booth. 1978. The boron requirement for root development in stem cuttings of Phaseolus aureus Roxb. New Phytol. 81:287-297, https://doi.org/10.1111/ j.1469-8137.1978.tb02634.x.

Mills, H.A. and J.B. Jones, Jr. 1996 Plant Nutrition Hand-book II. Micro-Macro Publ., Athens, GA.

Miller, C.H. and L.W. Nielsen. 1970. Sweet potato blister, a disease associated with boron nutrition. J. Amer. Soc. Hort. Sci. 95:685-686.

Nable, R.O., B. Cartwright, and R.C. Lance. 1990. Genotypic differences in boron accumulation in barley: Relative susceptibilities to boron deficiency and toxicity, p. 243-251. In: N. El Bassam, M. Dambroth, and B. Loughman (eds.). Genetic aspects of plant mineral nutrition. Springer, Dordrecht, The Netherlands, https:// doi.org/10.1007/978-94-009-2053-8_38.

Nable, R.O., G.S. Bañuelos, and J.G. Paull. 1997. Boron toxicity. Plant Soil 193:181-198, https:// doi.org/10.1023/A:1004272227886.

Nakatani, M. and Y. Watanabe. 1986. Effects of soil temperatures on the rooting of cut-sprouts of sweet Potato (Ipomoea batatas Lam.): I. Optimum soil temperature for rooting and effects of high soil temperatures on the physiological and anatomical characteristics of roots. Proc. Crop Sci. Soc. Jpn. 55:208-216, https:// doi.org/10.1626/jcs.55.208.

O'Sullivan, J.N., C.J. Asher, and F.P.C. Blarney. 1997. Nutrient disorders of sweet potato. ACIAR Monograph No. 48. Australian Centre for International Agricultural Research, Canberra.

Oertli, J.J. 1993. The mobility of boron in plants. Plant Soil 155-156:301-304, https://doi.org/ 10.1007/978-94-011-1880-4_80.

Prasad, R.Y., S. Shivay, and D. Kumar. 2016. Interactions of zinc with other nutrients in soils and plants-A Review. Indian J. Fert. 12:16-26.

Princi, M.P., A. Lupini, F. Araniti, C. Longo, A. Mauceri, F. Sunseri, and M.R. Abenavoli. 2016. Boron toxicity and tolerance in plants: Recent advances and future perspectives, p. 115-147. In: P. Ahmad (ed.). Plant metal interaction - emerging remediation techniques. Elsevier, Amsterdam, https://doi.org/ 10.1016/B978-0-12-803158-2.00005-9.

R Development Core Team. 2019. R: A language and environment for statistical computing. Vienna, Austria: R Foundation for Statistical Computing.

Reid, R. 2007. Physiology and metabolism of boron in plants, p. 83-90. In: F. Xu, H.E. Goldbach, P.H. Brown, R.W. Bell, T. Fujiwara, C.D. Hunt, S. Goldberg, and L. Shi (eds.) Advances in plant and animal boron nutrition. Springer, Dordrecht, The Netherlands, https:// doi.org/10.1007/978-1-4020-5382-5_7.

Rolston, L.H., C.A. Clark, J.M. Cannon, W.M Randle, E.G. Riley, P.W. Wilson, and M.L. Robbins. 1987. 'Beauregard' sweet potato. HortScience 26:1338-1339.

Schneider, C.A., W.S. Rasband, and K.W. Eliceiri. 2012. NIH Image to ImageJ: 25 years of image analysis. Nat. Methods 9:671-675, https://doi. org/10.1038/nmeth.2089.

Schultheis, J.R. and C.R. Campbell. 1996. Influence of boron rate, timing, and application method on skin discoloration of 'Hernandez' sweetpotato. HortScience 31:593 (abstr.).

Scott, L.E. and J.C. Bouwkamp. 1974. Seasonal mineral accumulation by the sweet potato. HortScience 9:233-235.

Seethepalli, A. and L.M. York. 2020. RhizoVision Explorer - interactive software for generalized root image analysis designed for everyone. 2.0.2. https://doi.org/10.5281/zenodo.4095629.

Shorrocks, V.M. 1997. The occurrence and correction of boron deficiency. Plant Soil 193:121148, https://doi.org/10.1023/A:1004216126069.

Sinha, P., R. Jain, and C. Chatterjee. 2000. Interaction effect of boron and zinc on growth and metabolism of mustard. Commun. Soil Sci. Plant Anal. 31:41-49, https://doi.org/10.1080/ 00103620009370419.

Steinburg, R.A., A.W. Specht, and E.M. Roller. 1955. Effect of micronutrient deficiency on mineral composition, nitrogen fraction, ascorbic acid and burn of tobacco grown flowering in water culture. Plant Physiol. 30:123-129.

Tanaka, M. and T. Fujiwara. 2008. Physiological roles and transport mechanisms of boron: Perspectives from plants. Eur. J. Phys. 456:671677, https://doi.org/10.1007/s00424-007-0370-8.
Tariq, M. and C.B. Mott. 2007. The significance of boron in plant nutrition and environment-a review. J. Agron. 6:1-10, https://doi.org/10.3923/ ja.2007.1.10.

Togari, Y. 1950. A study of tuberous root formation in sweet potato [Japanese with English summary]. Bull. Nat. Agr. Exp. Sta. Tokyo 68:1-96.

Villordon, A., D.R. LaBonte, N. Firon, Y. Kfir, E. Pressman, and A. Schwartz. 2009. Characterization of adventitious root development in sweetpotato. HortScience 44:651-655, https:// doi.org/10.21273/HORTSCI.44.3.651.

Villordon, A., D. LaBonte, J. Solis, and N. Firon. 2012. Characterization of lateral root development at the onset of storage root initiation in 'Beauregard' sweetpotato adventitious roots. Hort Science 47:961-968, https://doi.org/10.21273/ HORTSCI.47.7.961.

Villordon, A., D. Labonte, N. Firon, and E. Carey. 2013. Variation in nitrogen rate and local availability alter root architecture attributes at the onset of storage root initiation in 'Beauregard' sweetpotato. HortScience 48:808-815, https:// doi.org/10.21273/HORTSCI.48.6.808

Villordon, A.Q. and C.C. Clark. 2014. Variation in virus symptom development and root architecture attributes at the onset of storage root initiation in 'Beauregard' sweetpotato plants grown with or without nitrogen. PLoS One 9:e107384, https://doi.org/10.1371/journal.pone.0107384.

Villordon, A. and C. Clark. 2018. Variation in root architecture attributes at the onset of storage root formation among resistant and susceptible sweetpotato cultivars infected with Meloidogyne incognita. HortScience 53:1924-1929, https://doi.org/10.21273/HORTSCI10746-18.

Villordon, A., J.C. Gregorie, and D. LaBonte. 2020. Variation in phosphorus availability, root architecture attributes, and onset of storage root formation among sweetpotato cultivars. HortScience 55:1903-1922, https://doi.org/10.21273/ HORTSCI15358-20.

Wickham, H. 2009. ggplot2: Elegant graphics for data analysis. Springer, New York, https://doi. org/10.1007/978-3-319-24277-4.

Wilson, L.A. and S.B. Lowe. 1973. The anatomy of the root system in West Indian sweet potato (Ipomoea batatas (L.) Lam.) cultivars. Ann. Bot. 37: 633-643, https://doi.org/10.1093/oxfordjournals. aob.a084814. 


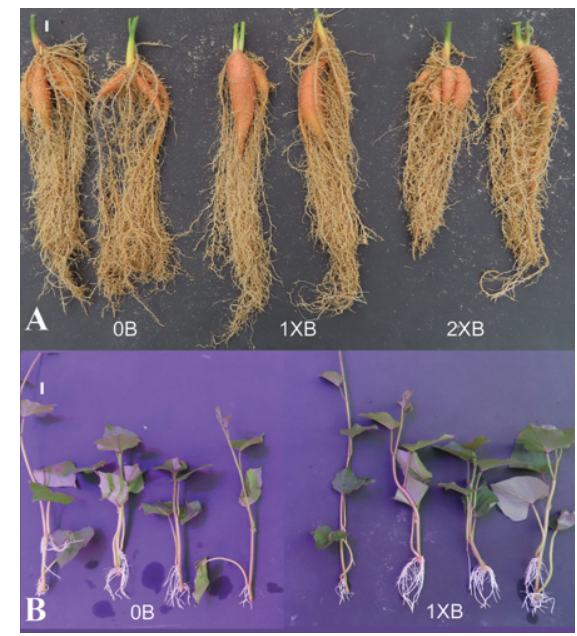

Supplemental Fig. 1. Storage root development at $50 \mathrm{~d}$ in sweetpotato cultivar Beauregard grown in three boron levels (A). Adventitious root development at $5 \mathrm{~d}$ in sweetpotato cultivar Beauregard cuttings grown in nutrient solutions with $0.5 \mathrm{mg} \cdot \mathrm{kg}^{-1}$ boron and without boron $(\mathbf{B})$. Scale bar $=1 \mathrm{~cm}$. Boron levels: $0 \mathrm{~B}=\mathrm{B}$ was omitted in the nutrient solution, substrate $\mathrm{B}=0.1 \mathrm{mg} \cdot \mathrm{kg}^{-1} ; 1 \mathrm{XB}=0.5 \mathrm{mg} \cdot \mathrm{kg}^{-1} ; 2 \mathrm{XB}=1 \mathrm{mg} \cdot \mathrm{kg}^{-1}$.

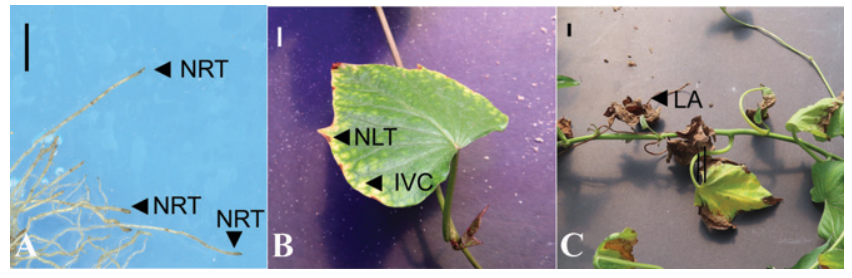

Supplemental Fig. 2. Symptoms associated with boron deficiency and toxicity in sweetpotato cultivars: 'Okinawa' adventitious roots at $15 \mathrm{~d}$ from plants grown without boron $(\mathbf{A})$; 'Beauregard' leaf tissue at $15 \mathrm{~d}(\mathbf{B})$ and $50 \mathrm{~d}(\mathbf{C})$ from plants grown with excessive boron. IVC = interveinal chlorosis; NLT $=$ necrotic leaf tissue; NRT $=$ necrotic root tip; LA = leaf abscission.

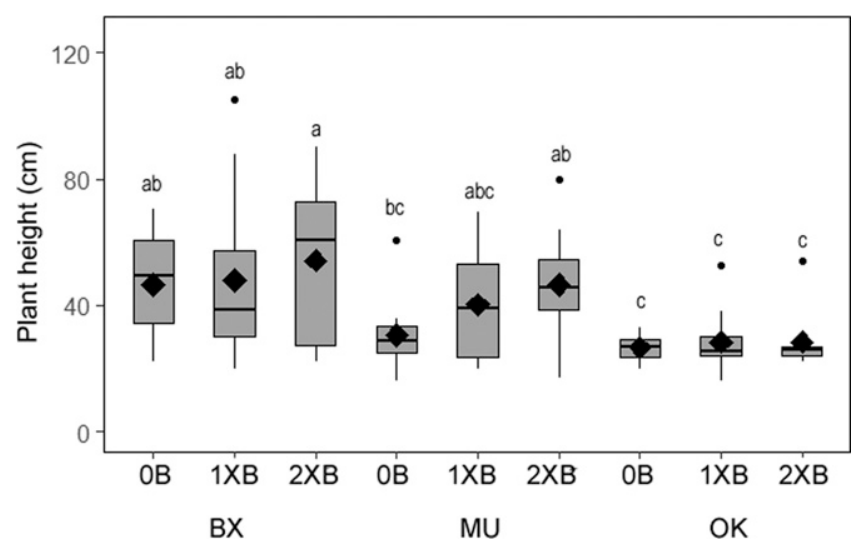

Supplemental Fig. 3. Box plots of plant height of three sweetpotato cultivars grown in three boron levels. Boxes represent the interquartile range (IQR, or middle $50 \%$ ) of values for each feature. Shaded diamonds represent mean values. Bold horizontal lines indicate median values. Upper box plot whiskers represent the last data point within the range of $75 \%$ quantile $+1.5 \mathrm{IQR}$, lower box plot whiskers represent the last data point within the range of $25 \%$ quantile - 1.5 IQR. Mean comparisons were performed on transformed data; corresponding nontransformed values are shown. Boxes with different letters differ significantly at the $5 \%$ level by Fisher's least significant difference. Boron levels: $0 \mathrm{~B}=\mathrm{B}$ was omitted in the nutrient solution, substrate $\mathrm{B}=$ $0.1 \mathrm{mg} \cdot \mathrm{kg}^{-1} ; 1 \mathrm{XB}=0.5 \mathrm{mg} \cdot \mathrm{kg}^{-1} ; 2 \mathrm{XB}=1 \mathrm{mg} \cdot \mathrm{kg}^{-1}$. Data were combined from two planting dates; plant height was measured at $15 \mathrm{days}$. 
Cultivar

\begin{tabular}{|c|c|c|c|}
\hline \multirow[b]{2}{*}{ Nutrient } & \\
\hline & Beauregard & Murasaki & Okinawa \\
\hline $\mathrm{N}, \%$ & $3.6 \pm 0.19$ & $3.5 \pm 0.09$ & $3.1 \pm 0.06$ \\
\hline $\mathrm{P}, \%$ & $0.26 \pm 0.017$ & $0.28 \pm 0.0$ & $0.25 \pm 0.03$ \\
\hline $\mathrm{K}, \%$ & $2.3 \pm 0.04$ & $2.1 \pm 0.19$ & $1.9 \pm 0.25$ \\
\hline $\mathrm{Mg}, \%$ & $0.43 \pm 0.03$ & $0.46 \pm 0.03$ & $0.44 \pm 0.02$ \\
\hline $\mathrm{S}, \%$ & $0.23 \pm 0.02$ & $0.12 \pm 0.05$ & $0.20 \pm 0.03$ \\
\hline $\mathrm{B}, \mathrm{mg} \cdot \mathrm{kg}^{-1}$ & $32.0 \pm 2.1$ & $40.5 \pm 3.5$ & $40.0 \pm 2.0$ \\
\hline $\mathrm{Cu}, \mathrm{mg} \cdot \mathrm{kg}^{-1}$ & $8.0 \pm 1.0$ & $7.0 \pm 0.0$ & $6.5 \pm 0.5$ \\
\hline $\mathrm{Al}, \mathrm{mg} \cdot \mathrm{kg}^{-1}$ & $33.7 \pm 3.8$ & $41.5 \pm 21.5$ & $26.0 \pm 5.0$ \\
\hline $\mathrm{Zn}, \mathrm{mg} \cdot \mathrm{kg}^{-1}$ & $44 \pm 6.6$ & $41 \pm 3.0$ & $47 \pm 1.0$ \\
\hline
\end{tabular}

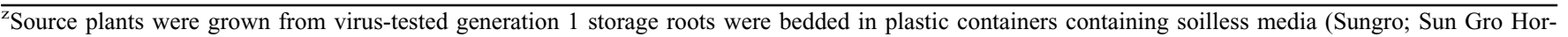
ticulture, Bellevue, WA).

Supplemental Table 2. Laboratory analysis results of the growth substrate used in the study as well as samples from each boron treatment. ${ }^{z}$

\begin{tabular}{|c|c|c|c|c|}
\hline Nutrient & \multicolumn{4}{|c|}{$\left(\mathrm{mg} \cdot \mathrm{kg}^{-1}\right)$} \\
\hline Phosphorus & $3.0 \pm 0.6$ & $8.7 \pm 0.7$ & $7.7 \pm 0.3$ & $12.3 \pm 0.3$ \\
\hline Calcium & $135 \pm 37$ & $107 \pm 5$ & $105 \pm 3$ & $172 \pm 27$ \\
\hline Magnesium & $17 \pm 0$ & $21 \pm 0.6$ & $25 \pm 1.2$ & $21 \pm 0.3$ \\
\hline Sulfur & $3.7 \pm 0.7$ & $13.3 \pm 1.8$ & $14.0 \pm 1.6$ & $10.0 \pm 3.2$ \\
\hline Boron & $0.1 \pm 0.0$ & $0.1 \pm 0.0$ & $0.1 \pm 0.0$ & $0.2 \pm 0.03$ \\
\hline Manganese & $2.3 \pm 0.3$ & $2.0 \pm 0.0$ & $4.0 \pm 0.6$ & $2.7 \pm 0.3$ \\
\hline Zinc & $0.17 \pm 0.03$ & $0.10 \pm 0.0$ & $0.27 \pm 0.03$ & $0.23 \pm 0.03$ \\
\hline Sodium & $7.3 \pm 0.3$ & $6.3 \pm 0.3$ & $7.0 \pm 0.7$ & $7.0 \pm 0.6$ \\
\hline $\mathrm{pH}$ & $6.5 \pm 0.03$ & $7.0 \pm 0.06$ & $6.9 \pm 0.03$ & $6.7 \pm 0.07$ \\
\hline Organic matter & $0.23 \pm 0.07$ & $0.30 \pm 0.06$ & $0.27 \pm 0.03$ & $0.2 \pm 0.06$ \\
\hline
\end{tabular}

${ }^{\mathrm{z}}$ Values represent means $( \pm \mathrm{SE})$. Treated substrate samples were collected at $15 \mathrm{~d}$. 1X Hoagland's was used as the base nutrient solution with different boron (B) levels: $0 \mathrm{~B}=\mathrm{B}$ was omitted in the nutrient solution, substrate $\mathrm{B}=0.1 \mathrm{mg} \cdot \mathrm{kg}^{-1} ; 1 \mathrm{XB}=0.5 \mathrm{mg} \cdot \mathrm{kg}^{-1} ; 2 \mathrm{XB}=1 \mathrm{mg} \cdot \mathrm{kg}^{-1}$. 